\title{
FILOZOFIA
}

https://doi.org/10.15633/sts.4189

KS. ŁUKASZ LIBOWSKI

Studia Sandomierskie

(D) https://orcid.org/0000-0001-6175-0823

Katolicki Uniwersytet Lubelski Jana Pawła II

$28(2021)$

\section{O METODZIE DOCIEKAŃ IMAGOLOGICZNYCH}

\begin{abstract}
Wstęp
W niniejszym tekście ${ }^{1}$ z zakresu metodologii literaturoznawstwa autor zamierza omówić, jak powinno się prowadzić dociekania imagologiczne. Podaje tu zatem garść informacji, których winien być świadomy literaturoznawca przystępujący do tego rodzaju rozważań ${ }^{2}$. Owe refleksje imagologiczne rozumie się tu szeroko, zaliczając do nich wszystkie badania, których przedmiotem jest obraz jakiegokolwiek drugiego - innego, obcego - człowieka.

Paragraf pierwszy wyjaśnia trzy podstawowe pojęcia imagologiczne. Paragraf drugi omawia kwestię doboru materiału źródłowego w ramach badań imagologicznych. W paragrafie trzecim charakteryzuje się możliwe sposoby opracowywania wyselekcjonowanego materiału, tj. możliwe profile odnośnych poszukiwań. W końcu w paragrafie czwartym przedstawia się kilka najważniejszych ustaleń imagologii, wskazując związane z nimi momenty analizy imagologicznej, w których badacz powinien zachować szczególną ostrożność.
\end{abstract}

\section{Objaśnienie podstawowych pojęć imagologii}

Przed zajęciem się właściwym przedmiotem niniejszych rozważań trzeba się zapoznać z podstawowymi pojęciami imagologii. Tym bardziej że jest to dyscyplina naukowa stosunkowo młoda i jej aparatura pojęciowa nie jest powszechnie znana.

1 Przedkładany tu materiał pierwotnie został wygłoszony jako referat pt. Obrazołap: jedno z narzędzi $w$ warsztacie badawczym filologa klasycznego. Czyli o metodzie dociekań imagologicznych w obrębie literatur greckiej i łacińskiej w czasie ogólnopolskiej interdyscyplinarnej studencko-doktoranckiej konferencji naukowej $M y$, wy, oni. Co i jak starożytni myśleli o sobie i innych?, którą 15 maja 2020 r. zorganizowało online Koło Naukowe Klasyków działające przy Katolickim Uniwersytecie Lubelskim Jana Pawła II. Referat tym przede wszystkim różnił się od prezentowanego tekstu, że był pomyślany jako pewien przewodnik imagologiczny dla filologów klasycznych. Na ten temat: zob. W. Nippel, Ethnic Images in Classical Antiquity, w: Imagology: The Cultural Construction and Literary Representation of National Characters: A Critical Survey, eds. M. Beller, J. Leerssen, Studia Imagologica 13, Amsterdam-New York 2007, s. 31-44.

2 Por. J. Leerssen, Identity/Alterity/Hybridity, w: Imagology ..., dz. cyt., s. 26-32. 
Dość o imagologii powiedzieć, że choć jej historia sięga wczesnej nowożytności, a dokładniej - jak się przyjmuje - czasu aktywności włoskiego humanisty, znanego jako Jules César Scaliger, to za jej właściwy początek uznaje się okres po drugiej wojnie światowej³ . Wydaje się, że w tym miejscu należy omówić trzy pojęcia: innego/obcego, obrazu i etnotypu - oczywiście na poziomie przyczynkarskim.

Pierwsze z wymienionych pojęć jest być może najtrudniejsze do wyjaśnienia, przede wszystkim z tej racji, że na temat inności/obcości istnieje obszerna literatura przedmiotowa ${ }^{4}$. Co do tej literatury, wystarczy zaznaczyć, że nie jej obszerność stanowi zasadniczy problem, lecz duże zróżnicowanie merytoryczne. Poszczególni autorzy, których prace do niej należą, reprezentują bowiem różne dyscypliny naukowe i wyrastają z różnych tradycji filozoficznych, które nie przystają do siebie ani też nie dają się łatwo przełożyć jedna na drugą. Ponieważ jednak dla niniejszego przedsięwzięcia badawczego, a chyba też i w ogóle dla uprawiania imagologii wystarcza podstawowe rozumienie inności/obcości, można sięgnąć do definicji słownikowych.

Podążając za myślą Joepa Leerssena, pojęcie inności/obcości rozpatruje się tu w kontekście pojęcia przeciwnego, tj. pojęcia tożsamości $i^{5}$. W słowniku Witolda Doroszewskiego można przeczytać, że tożsamość to «bycie tym samym; identyczność» ${ }^{6}$. Joanna Przyklenk, wyróżniwszy pięć współczesnych znaczeń słowa „tożsamość" i uporządkowawszy je od najogólniejszego do najwęższego, podsumowuje, że element wspólny wszystkich definicji ujmuje następująca formuła: „bycie takim samym, identycznym, jednakowym lub prawie identycznym, prawie jednakowym,

3 Zob. J. Leerssen, Imagology: History and Method, w: Imagology..., dz. cyt., s. 17-26; A. Hölter, Colonialism, w: Imagology..., dz. cyt., s. 304-306; J. Riesz, Postcolonialism, w: Imagology..., dz. cyt., s. 400-403; A. Rigney, Semiotics, w: Imagology..., dz. cyt., s. 421-424; J. Leerssen, The Poetics and Anthropology of National Character (1500-2000), w: Imagology..., s. 63-75; R. Corbey, Anthropology, w: Imagology..., dz. cyt., s. 263-266.

4 Zob. np. G. Agamben, Homo sacer. Suwerenna władza i nagie życie, thum. M. Salwa, Warszawa 2008; Z. Baumann, Obcy u naszych drzwi, Warszawa 2019; Z. Benedyktowicz, Portrety „,obcego”. Od stereotypu do symbolu, Kraków 2000; M. Buber, Ja i Ty. Wybór pism filozoficznych, tłum. J. Doktór, Warszawa 1992; M. Buchowski, Zrozumieć Innego. Antropologia racjonalności, Kraków 2004; H. Gruchlik, Inność a obcość w kontekście filozoficznym, „Anthropos?” (2007), nr 8-9, anthropos.us.edu.pl/anthropos5/texty/gruchlik. htm [dostęp: 15 XII 2020 r.]; R. Kapuściński, Ten Inny, Kraków 2020; Obcy/Inny-propozycje aplikacji pojęciowych, red. M. Karwatowska i in., Lublin 2018; E. Lévinas, Całość i nieskończoność. Esej o zewnętrzności, thum. M. Kowalska, Warszawa 2002; M. Środa, Obcy, inny, wykluczony, Gdańsk 2020; J. Tischner, Filozofia dramatu, Kraków 2006; J. Tischner, Inny. Eseje o spotkaniu, Kraków 2017; T. Todorov, Podbój Ameryki. Problem innego, tłum. J. Wojcieszak, Warszawa 1996; B. Waldenfels, Topografia obcego. Studia z fenomenologii obcego, tłum. J. Sidorek, Warszawa 2002.

5 J. Leerssen, Identity/Alterity/Hybridity, art. cyt., s. 335-342.

6 Tożsamość, zn. 1, w: Słownik języka polskiego, red. W. Doroszewski, Warszawa 19581969, sjpd.pwn.pl/haslo/to\%C5\%BCsamo\%C5\%9B\%C4\%87 [dostęp: 15 XII 2020 r.]. 
bardzo podobnym"'. Jeśli zatem po jednej stronie znajduje się tożsamość, to po drugiej stronie jako jej antonim stoi inność. Słownik podaje, że inność to «odznaczanie się cechami różniącymi daną rzecz czy osobę od innej; różność, odrębność, odmienność, bycie innym $»^{8}$ oraz że inny to «nie ten, lecz istniejący obok osoby czy rzeczy wymienionej, nie ten sam, drugi, dalszy, pozostały, nie taki, nie taki sam, niepodobny do drugiego, różny, odmienny, zmieniony, nowy» ${ }^{9}$. Pojęcia inności i innego przyrównuje się do pojęć obcości i obcego, używanych z nimi zamiennie. Takie postępowanie jest uzasadnione, gwoli ścisłości trzeba jednak zaznaczyć, że zakresy semantyczne pojęć inności i innego oraz obcości i obcego niezupełnie się pokrywają ${ }^{10}$. O obcym można przeczytać u Doroszewskiego, że jest to ktoś «nie należący do jakiegoś kręgu osób, spraw, rzeczy; zewnętrzny względem czego, niewłaściwy komu, nie objęty czyimś zainteresowaniami; cudzy» ${ }^{11}$; z kolei o słowie „obcość” z tego samego źródła można się dowiedzieć, że jest to rzeczownik urobiony od przymiotnika „obcy”"2.

Drugie ze wskazanych do omówienia pojęć, czyli „obraz”, jako fundamentalne dla imagologii jest z owych trzech terminów chyba najistotniejsze. Wszak imagologia, co wynika z samej jej nazwy, jest nauką o obrazie. Jej nazwę tworzą przecież dwa człony, „imago-” i „-logia”, z których pierwszy jest łacińskim rzeczownikiem imago - «obraz» $\rangle^{13}$, a drugi formą urobioną od wieloznacznego greckiego rzeczownika $\lambda$ ó $\varsigma^{14}{ }^{14}$, a zatem formą zwyczajowo wykorzystywaną do tworzenia nazw poszczególnych, choć nie wszystkich nauk. Warto jednak zaznaczyć, że wbrew temu, co mogłoby się wydawać w oparciu o etymologię jej nazwy, imagologii nie interesuje jakikolwiek obraz. Interesuje ją jedynie obraz konkretny, obraz określonego rodzaju, tzn. obraz innego/obcego. I to jeszcze innego/obcego - znów trzeba dodać, aby jeszcze precyzyjniej wskazać przedmiot imagologii - nie w szerokim sensie tego słowa, lecz pojętego jako przedstawiciela innego/obcego narodu albo państwa lub innej/obcej wspólnoty, grupy ludzkiej. Odnośnie do nazwy ,imagologia” warto przytoczyć zatem słowa Leerssena. Autor ten bowiem stwierdza, że „imagologia”

7 J. Przyklenk, Od identyczności do różnicy - uwagi o pojęciu tożsamości w najnowszej historii polszczyzny, w: Naukovi zapiski nacionalnogo universitetu „Ostroz'ka akademia”, Kulturologia 18, Ostrog 2017, s. 63.

8 Inność, w: Stownik języka polskiego, dz. cyt., sjpd.pwn.pl/haslo/inno\%C5\%9B\%C4\%87 [dostęp: 15 XII 2020 r.].

9 Inność, art. cyt.

${ }^{10}$ W tym kontekście: zob. np. M. Środa, Obcy, inny, wykluczony, dz. cyt.; Obcy/Inny..., dz. cyt.; Z. Baumann, Obcy u naszych drzwi, dz. cyt.; H. Gruchlik, Inność a obcość..., art. cyt.

${ }_{11}$ Obcy, w: Stownik języka polskiego, dz. cyt., sjpd.pwn.pl/haslo/obcy/ [dostęp: 15 XII 2020 r.].

${ }_{12}$ Obcość, w: Stownikjęzyka polskiego, dz. cyt., sjpd.pwn.pl/haslo/obco\%C5\%9B\%C4\%87/ [dostęp: 15 XII 2020 r.].

13 Imago, w: Stownik tacińsko-polski, red. M. Plezia, t. 3, Warszawa 2007, s. 32-33.

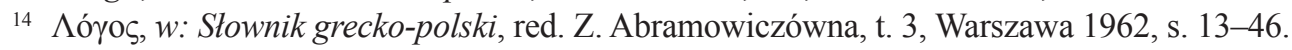


to „termin, któremu daleko do doskonałości, ale jest już zbyt utarty, by go podważać” ${ }^{15}$. Można domniemywać, że Leerssen ma tu na myśli przede wszystkim niejednoznaczność tego pojęcia.

Do jakiej rzeczywistości imagolodzy odnoszą pojęcie obrazu? Co takiego rozumieją przez obraz? Otóż przyjmują, że obraz to reprezentacja osoby, jakieś grupy, wspólnoty etnicznej albo narodu ${ }^{16}$. Odwołując się do klasycznego definiowania, można powiedzieć, że kategoria reprezentacji stanowi w tym wypadku rodzaj najbliższy (genus proximum) obrazu ${ }^{17}$, wzięte natomiast łącznie kategorie osoby, grupy, wspólnoty etnicznej i narodu wyznaczają różnicę gatunkową (differentia specifica). Inaczej mówiąc, obraz - zdaniem imagologów - należy do zbioru reprezentacji, z tym że spośród wszystkich reprezentacji wyróżnia go to, że jest reprezentacją osoby, grupy, wspólnoty etnicznej albo narodu. Reprezentacja, o jakiej mowa, może mieć dwojaki charakter: mentalny albo dyskursywny, a więc może należeć albo do rzeczywistości myślowej, intelektualnej, albo do rzeczywistości werbalnej, słownej. Ponieważ imagologia jest nauką humanistyczną, poddziedziną literaturoznawstwa i ponieważ właściwym jej żywiołem jest tekst, zajmuje się zasadniczo dyskursywnym obrazem innego/obcego ${ }^{18}$. Mentalnym obrazem innego/obcego zajmuje się o tyle, o ile odnośna rzeczywistość mentalna ujęta jest w tekście.

Do tej zasadniczej charakterystyki imagologicznego pojęcia obrazu należy dodać pięć uwag różnej natury, jeszcze bardziej dookreślających jego zakres semantyczny ${ }^{19}$.

Po pierwsze, obrazu, o jakim mowa, nie tworzy wszystko, co w danym tekście czy danych tekstach jest powiedziane na temat konkretnej osoby, grupy czy konkretnego kraju. Otóż zdania stwierdzające empirycznie sprawdzalne fakty o danej osobie czy narodzie nie wnoszą niczego do tego obrazu. Jeśli zatem ktoś interesuje się obrazem innego/obcego w jakimś tekście, musi szukać w tym tekście zdań, w których danej osobie czy narodowi przypisuje się cechy bądź to moralne, bądź to charakterologiczne. $Z$ tym że takie atrybucje nie są często sformułowane wprost, lecz tak, że jakiś

15 J. Leerssen, Imagologia. O zastosowaniu etniczności do nadawania światu sensu, „Porównania" 21 (2017), $\mathrm{nr} 2, s .10$.

16 J. Leerssen, Image, w: Imagology..., dz. cyt., s. 342-344; zob. także: H. Dyserinck, Komparatistik: Eine Einführung, Bonn 1997; H. Dyserinck, Von Ethnopsychologie zu Ethnoimagologie: Über Entwicklung und mögliche Endbestimmung eines Schwerpunkts des ehemaligen Aachener Komparatistikprograms, „Neohelicon” 29 (2002), Nr. 1, s. 57-74; H. Millas, The Imagined „, Other” as National Identity: Greeks and Turks, Ankara 2005; T. Mitchelli, What Is an Image?, w: Imagology: Images, Text, Ideology, ed. by T. Mitchelli, Chicago 1986, s. 7-46; D.H. Pageaux, De l'image à l'imaginaire, „Colloquium Helveticum" (1988), nr 7, s. 9-16.

17 Zob. A. Rigney, Representation, w: Imagology..., dz. cyt., s. 415-418.

18 Zob. A. Rigney, Discourse, w: Imagology ..., dz. cyt., s. 313-315.

19 Na podstawie: J. Leerssen, Image, art. cyt., s. 342-344; J. Leerssen, Imagologia..., art. cyt., s. 12-14, 16. 
określony fakt społeczny jest łączony z pewną właściwością psychiczną wspólną dla wszystkich członków tej społeczeństwa. Należy więc być czujnym i ostrożnie odróżniać jedno od drugiego, tj. fakt społeczny od właściwości społeczeństwa.

Po drugie, obraz imagologiczny nie jest stereotypem i nie wolno go z nim my$\operatorname{lic}^{20}$. Między jednym a drugim występuje bowiem istotna różnica. Podczas gdy stereotyp jest konstruktem trwałym, to zasadniczą cechą obrazu w nadawanym mu przez imagologów sensie - jak zresztą cechą wszystkiego, co dyskursywne - jest zmienność. I to zmienność w dwóch wymiarach, gdyż zmienia się zarówno treść obrazu, jak i jego waloryzacja, a zatem zarówno to, co niejako na tym obrazie widać, jak i to, jak ten obraz się wartościuje.

Po trzecie, obrazy, które rozważa imagologia, dzielą się na autoobrazy, a więc na obrazy reprezentujące swoich, i heteroobrazy, czyli obrazy stanowiące przedstawienie, odwzorowanie innych/obcych. Ów podział obrazów imagolodzy uznają za podstawowy. Przyjęto go, kiedy zaobserwowano, ,że opisy narodów [w obrębie poszczególnych dyskursów] odnosiły się przede wszystkim nie do zewnętrznej rzeczywistości antropologicznej, ale do opartej na opozycjach, dyskursywnej ekonomii opisów innych narodów, głównie wzdłuż osi Swój vs. Obcy”21.

Po czwarte, należy odnotować, że na gruncie imagologii obrazy innego/obcego nie są badane w aspekcie ich prawdziwości. Imagolog nie zastanawia się nad tym, czy dany obraz jest autentyczny, słuszny, czy nie. Jest to konsekwencja przyjmowanego przez imagologa założenia, że obrazy są niefalsyfikowalne: „Wartość ich prawdy empirycznej jest tak samo nierozstrzygalna, jak stwierdzenia «moja miłość jest jak czerwona, czerwona róża»" ${ }^{22}$. Imagolodzy powtarzają, że obrazy, którym poświęcają uwagę, są ,nawet nie fałszywe (not even wrong)" ${ }^{23}$. Badanie imagologiczne dąży przeto do zrozumienia nie społeczeństwa ani też dynamiki społecznej, lecz „logiki dyskursu i ustanowionego zestawu konwencji kulturowych i poetyckich" ${ }^{24}$. „Perspektywa badawcza, zamiast na prawdzie, skupia się [tu] na retorycznej i poetyckiej sile oddziaływania" ${ }^{25}$ danego obrazu innego/obcego. Obraz ten jest dla imagologa, jak już wiadomo, przedmiotem dyskursywnym, czyli tropem narracyjnym $\mathrm{i}$ formułą retoryczną, w efekcie czego śledzi on jego rolę w warstwie narracyjnej i retorycznej analizowanego tekstu.

Po piąte wreszcie, trzeba zauważyć, że niekoniecznie obrazy dyskursywne, które tu się charakteryzuje, muszą się nie zgadzać z realnym zachowaniem społecznym. W wielu bowiem, choć nie we wszystkich przypadkach obrazy te harmonizują z rzeczywistością. Tej przystawalności imagolog winien być świadomy, gdyż „dowodzi [ona] siły dyskursu, który inspiruje zachowania i rodzi ważne pytanie o to, jak po-

20 Zob. M. Beller, Stereotype, w: Imagology ..., dz. cyt., s. 429-434.

21 J. Leerssen, Imagologia ..., art. cyt., s. 12.

22 J. Leerssen, Imagologia ..., art. cyt., s. 16.

23 J. Leerssen, Imagologia ..., art. cyt., s. 16.

24 J. Leerssen, Imagologia ..., art. cyt., s. 16.

25 J. Leerssen, Imagologia ..., art. cyt., s. 16. 
wstają i objawiają się takie wzorce do inspiracji, tj. jak modele ról kulturowych wpływają na wybory behawioralne"26.

$\mathrm{Na}$ ostatek pozostaje powiedzieć parę słów o pojęciu etnotypu. Pojęcie to jest w imagologii niezmiernie ważkie. Można by stwierdzić, że to etnotyp stanowi właściwy przedmiot zainteresowania tej nauki. Etnotyp to szczególny rodzaj obrazu innego/obcego. Jest to mianowicie konkretny obraz konkretnego innego/obcego; jest to taki właśnie, a nie inny obraz danego innego/obcego. O etnotypach Leerssen powiada, że „wyodrębniają one naród z reszty ludzkości poprzez przypisywanie mu określonego typu, tj. temperamentu lub predyspozycji psychologicznej, która motywuje i wyjaśnia dany sposób zachowania"27. Autor ten formułuje także negatywną wersję objaśnienia, czym jest etnotyp, kładąc akcent na jego moc eksplanacyjną: „Opisy określonego narodu, które w żaden sposób nie wyjaśniają narodowych cech za pomocą domniemanego ukrytego typu narodowego, nie są etnotypami i pozostają poza kręgiem zainteresowań badań imagologicznych (na przykład «Szwecja jest monarchią o zimnym klimacie i silnym systemie socjalnym»)"28. Tę grupę czy wspólnotę ludzi, do której odnosi się dany etnotyp, imagolodzy nazywają etnią ${ }^{29}$.

\section{Charakterystyka pierwszego etapu badań imagologicznych}

Zapoznawszy się z najniezbędniejszym słownikiem imagologii, można przejść do właściwej części rozważań, czyli do refleksji na temat metody badań imagologicznych. Wywód ten opiera się na niewielkim studium O pisaniu historii filozofii Władysława Tatarkiewicza ${ }^{30}$. Wydaje się bowiem słuszne, żeby w ramach imagologii tak myśleć o pracy z tekstem, jak myśli się o niej na gruncie historii filozofii.

$\mathrm{Na}$ początek wypada zdefiniować podstawowe tutaj pojęcie metody imagologicznej. Otóż jeśli przez imagologię rozumie się naukę, a funkcjonalnie i pragmatycznie idąc jeszcze dalej - zbiór tekstów dostarczających rozmaitego rodzaju twierdzeń o rzeczywistości obrazu innego/obcego, to metoda imagologiczna z konieczności musi oznaczać zestaw czynności, które prowadzą do powstania nowego tekstu tego właśnie rodzaju. Rzecz jasna, jeśli ów ciąg czynności ma stanowić metodę naukową, musi spełniać określone warunki, które formułuje ogólna metodologia nauk. Musi być m.in. przemyślany i zaplanowany, ekonomiczny i efektywny ${ }^{31}$. Ponieważ imagologiczną procedurę badawczą pojmuje się tu jako zbiór różnych czynności, których wykonanie skutkuje powstaniem tekstu określonego typu, to okazuje się ona złożona

26 J. Leerssen, Imagologia ..., art. cyt., s. 13.

27 J. Leerssen, Imagologia ..., art. cyt., s. 14.

28 J. Leerssen, Imagologia ..., art. cyt., s. 14.

29 Zob. J. Leerssen, Nation, Ethnie, People, w: Imagology..., dz. cyt., s. 377-381.

${ }^{30}$ W. Tatarkiewicz, O pisaniu historii filozofii, w: W. Tatarkiewicz, O filozofii i sztuce, Warszawa 1986, s. 63-86.

31 Por. Z. Hajduk, Ogólna metodologia nauk, Lublin 2012, s. 71-74; T. Kotarbiński, O pojęciu metody, Warszawa 1957; A. Bronk, Metoda naukowa, w: Encyklopedia katolicka, red. Stanisław Wilk i in., t. 12, Lublin 2008, k. 637-644. 
z wielu etapów. Ostatnim z tych etapów jest redagowanie nowego tekstu imagologicznego, a zatem tekstu, w którym orzeka się coś o przedmiocie imagologicznym.

Etap ostatni, a więc etap pisania, można pominąć - tak jak postępuje Tatarkiewicz w swoim opisie metody historycznofilozoficznej ${ }^{32}$. Pomoże to zatrzymać się tutaj wyłącznie na tym, co znamienne i zasadnicze dla imagologii. W takim razie wśród wszystkich etapów składających się na rozpatrywaną metodę można wyróżnić etapy dwu rodzajów. Etapami rodzaju pierwszego byłyby te związane z wyborem określonego materiału tekstowego, etapami rodzaju drugiego - te związane z porządkowaniem wyselekcjonowanego materiału. Etapy pierwszego rodzaju, biorąc je tymczasem łącznie, nazywa się tu pierwszym etapem metody imagologii. Podobnie etapy rodzaju drugiego bierze się tu na ten moment łącznie, nazywając je etapem wtórym metody imagologicznej.

W tym miejscu warto poczynić trzy krótkie uwagi stanowiące najogólniejszą charakterystykę dociekania koncentrującego się na rzeczywistości obrazu innego/ obcego, dotyczące obydwu wyróżnionych etapów tego postępowania naukowego.

Po pierwsze, oba etapy, o których się tu mówi, polegają na pracy z tekstem, chociaż praca ta na każdym z tych etapów, co najzupełniej zrozumiałe, wygląda inaczej. Można to ująć następująco: na etapie pierwszym pracuje się bliżej tekstu, będąc wobec niego bardziej biernym, tj. wychwytując te jego fragmenty, które odnoszą się do fenomenu obrazu innego/obcego, natomiast na etapie wtórym pracuje się dalej od tekstu, podchodząc do niego raczej aktywnie, tj. kreatywnie, twórczo go czytając i interpretując. Z tym że pomiędzy pracą na etapie pierwszym a pracą na etapie wtórym nie ma ostrej cezury. Przejście z pierwszej z tych prac do drugiej jest nieostre, płynne.

Po drugie, każdy z opisanych dwóch etapów jest tak samo ważny. Uwaga ta brzmi banalnie, lecz jest relewantna. Może się bowiem wydawać, że w badaniu imagologicznym istotniejszy jest jego odcinek drugi, w którym opracowuje się wyjątki zgromadzone w trakcie uprzedniej analizy tekstu. Na wtórym odcinku dociekań imagologicznych badacz musi się przecież wykazać inicjatywą, musi wnieść do swoich badań coś od siebie. Naturalnie można pozwolić sobie na takie stwierdzenie na podstawie założenia, że w parach pojęć bierność - aktywność oraz rozczłonkowywanie - łączenie pojęcia występujące na drugim miejscu bodaj powszechnie uważa się za lepsze czy ważniejsze. Tymczasem jednak tak nie jest, ponieważ pomysłowość interpretacyjna imagologa całkowicie zależy od materiału, jaki wcześniej pozyskał. Dopiero ów zebrany przez imagologa materiał niejako wyzwala, wywołuje w nim koncept, rodzi w jego umyśle ideę interpretacyjną.

I po trzecie, jeśli na wyróżnione dwa etapy metody badań imagologicznych patrzy się z perspektywy teoretycznej i logicznej, to trzeba przyznać, że stanowiąc zamknięte całości, są one od siebie niezależne oraz że następują po sobie, tzn. że etap organizowania i porządkowania materiału następuje po etapie jego zbierania. Prze-

$\overline{32}$ W. Tatarkiewicz, O pisaniu historii filozofii, art. cyt., s. 63-86. 
chodząc natomiast do praktyki, okazuje się, że etapy te są jednak ze sobą sprzęgnięte oraz że zachowanie następstwa jednego etapu po drugim nie tylko że nie jest konieczne, ale w ogóle jest niemożliwe. Zawsze bowiem badacz przeprowadza czynności właściwe dla tych dwóch etapów równocześnie. I to nie dlatego, że tak chce, lecz dlatego, że musi w ten sposób postępować. Żeby wszak pracować efektywnie na pierwszym etapie, trzeba wiedzieć, choćby tylko wstępnie, co będzie się robić na etapie następnym, trzeba mieć jakąś, choćby niewyraźną wizję całości. Żeby dobrze dobrać materiał tekstowy na pierwszym etapie dociekania imagologicznego, należy wiedzieć, jak się będzie potem obchodziło i postępowało z tym materiałem na etapie wtórym. W niejednym przypadku od tej wiedzy o naturze i charakterze pracy na etapie drugim będzie zależeć, czy dany fragment tekstu uzna się za potrzebny i przynoszący jakieś ciekawe informacje z punktu widzenia prowadzonych badań, czy też nie. $Z$ kolei takie rozstrzygnięcie nie pozostaje często bez wpływu na ostateczny rezultat całego toku postępowania.

Dalsza część paragrafu zajmuje się już samą tylko pierwszą odsłoną imagologicznej procedury badawczej, starając się bardziej szczegółowo ją scharakteryzować. Choć nie ulega wątpliwości, że charakterystyki tej nie da się wyczerpująco przedstawić.

Pierwszy etap opisywanych badań ma na celu wyłuskanie z tekstów obranych jako źródło dla rozważań imagologicznych wszystkich tych fragmentów, w których pojawiają się wątki imagologiczne, a zatem wszystkich takich ustępów, w których jest mowa o obrazie innego/obcego. Czynności, jakie należy zaliczyć do pierwszego etapu metody imagologii, są więc w znaczniej mierze takie same jak w wypadku pierwszego etapu każdej innej metody literaturoznawczej, mającej tekst za punkt wyjścia: lektura tekstu źródłowego, wybór fragmentów tego tekstu, w których obecne są wątki imagologiczne, ocena wybranych fragmentów oraz selekcja materiału tekstowego do wykorzystania później. Trzeba zaznaczyć, że poprzestaje się tu ma czynnościach zasadniczych, nie niuansując nadmiernie kwestii.

Co do lektury, to należy rozróżnić lekturę wstępną, powierzchowną, a także właściwą, wnikliwą czy pogłębioną. Lektura tak jednego, jak drugiego rodzaju ma na celu zapoznanie się z całością tekstu, by badacz możliwie dobrze zorientował się w całym rozpatrywanym materiale. Takie poznanie całości wraz z nabyciem $w$ niej orientacji jest potrzebne co najmniej z dwóch racji. Po pierwsze, aby uchwycić główną myśl analizowanego tekstu, jego zasadnicze przesłanie. Po drugie zaś, aby określić rolę, jaką w tekście odgrywa etnotyp, konkretny, dany obraz innego/obcego, oraz aby uświadomić sobie, w jakim kontekście ów etnotyp jest tam umieszczony.

Trzy kolejne następujące po lekturze czynności, a więc wybór fragmentów danego tekstu, w których obecne są wątki imagologiczne, oszacowanie wartości czy przydatności tych fragmentów oraz wyznaczenie spośród nich materiału, który posłuży w dalszym postępowaniu naukowym, stanowią sedno pierwszego etapu badań imagologicznych. Ich to skutkiem jest, by tak rzec, ukonstytuowanie się obrazu innego/obcego, jaki zawiera się w danym źródle. 
Warto dodać, że oceny powinno się dokonywać, uwzględniając dwa czynniki. Czynniki te stanowią z jednej strony materiał zdobyty w ramach analizy badanego tekstu, z drugiej zaś strony to, co potem chce się z tym materiałem zrobić. Zwracając na tę rzecz uwagę, ukonkretnia się to, co odnotowano wyżej, a mianowicie, że dwa wyróżnione uprzednio etapy metody imagologicznej są ze sobą wzajemnie splecione.

Etap drugi metody refleksji imagologicznej stanowi, jak powiedziano, zorganizowanie materiału źródłowego otrzymanego wskutek przejścia przez etap pierwszy tej metody. O tym, jak można ułożyć zgromadzoną tekstową substancję imagologiczną, traktuje paragraf kolejny.

\section{Omówienie drugiego i kolejnych etapów badań imagologicznych}

Początek tego paragrafu może stanowić następujące stwierdzenie: to wtóry etap metody imagologicznej przesądza o wyniku, jaki przynosi zastosowanie tej metody. A jeśli tak, to właśnie od niego zależy, czy ze swoją pracą badacz znajdzie miejsce na targowisku idei, do czego przecież koniec końców dąży. Płynie stąd wniosek, że zawczasu, najlepiej już w chwili wstępnego projektowania badań, należy zadbać także - jeśli nie przede wszystkim - o ich atrakcyjność.

Przechodząc do meritum: Co można zrobić z materiałem uzyskanym w pierwszym etapie dociekań imagologicznych? Jak go obrobić? Albowiem jest on niejako surowcem, który trzeba przetworzyć, jeśli ma się do czegoś nadać. Można też zapytać inaczej: Element jakiej szerszej, bardziej złożonej procedury naukowej ma stanowić dociekanie imagologiczne? W ramach jakiego większego projektu będzie się czytać wybrane teksty w aspekcie imagologicznym? Odpowiedź na te pytania brzmi: istnieją dwie zasadnicze możliwości. Zebrany materiał źródłowy można wykorzystać albo w badaniach zakrojonych skromniej, albo w badaniach pomyślanych $\mathrm{z}$ rozmachem. Oba te określenia należy rozumieć w sensie opisowym, nie wartościującym. Charakteryzują one procedurę postępowania naukowego w pierwszym wypadku prostszą, w drugim zaś zaawansowaną. Warto przyjrzeć się dokładniej obu tym procedurom.

Badania pierwszego rodzaju mogą przybrać trzy skądinąd znane, konwencjonalne formy. Mogą zmierzać do rekonstrukcji obrazu innego/obcego bądź też ich celem może być przeanalizowanie dynamiki obrazu innego/obcego. Można je także pomyśleć jako porównanie odpowiadających sobie i równorzędnych obrazów innego/obcego. W literaturze przedmiotu o takim rozróżnieniu się nie mówi, warto jednak je wprowadzić, ponieważ wydaje się użyteczne i wiele wyjaśniające.

Rekonstrukcja obrazu to jego odtworzenie. Operację tę można uznać za niewiele wnoszącą do tego, co zwie się nauką, ale konstatacja taka byłaby błędna. Wyłożyć coś lepiej, niż zostało to wyłożone w źródle, odróżnić to, co ważne, od tego, co mniej istotne, znaleźć ogólniejsze sformułowania, nadać całości klarowną strukturę, w sposób zwarty uporządkować materiał - co przecież rozumie się przez rekonstrukcję - nie jest to bynajmniej proste. Warto to zauważyć, gdyż dzisiaj 
często nie docenia się badań tego rodzaju, utrzymując, że są na tyle prymitywne, iż zasadne jest odmówienie im miana pracy naukowej. Idąc dalej, można stwierdzić, że rekonstrukcja, o jakiej tu mowa, może być prosta albo pogłębiona, tzn. mniej lub bardziej skonfrontowana z pewnymi pytaniami. Odnośnie bowiem do każdego prostego przedstawieniu obrazu innego/obcego można postawić jakieś pytania. Próba odpowiedzi na te pytania byłaby właśnie rekonstrukcją pogłębioną. Inaczej mówiąc, pogłębiona rekonstrukcja obrazu innego/obcego polega na skomentowaniu tego obrazu, przedłożeniu pewnego jego rozumienia, jakiejś jego hermeneutyki.

Z kolei poprzez analizę dynamiki obrazu innego/obcego należy rozumieć prześledzenie zmian lub przekształceń, jakim ten obraz podlega czy to na przestrzeni pewnego określonego czasu, np. wybranej epoki, czy to w konkretnym utworze albo w korpusie pism jednego autora. W badaniu tego typu trzeba by spróbować nazwać owe zachodzące zmiany czy przekształcenia i podać ich charakterystykę. Wypadałoby również wskazać czynniki, pod wpływem których zaobserwowane modyfikacje zaszły, a ponadto skutki, jakie wywołały.

Wreszcie porównanie obrazów stanowi chyba czynność zrozumiałą samą przez się. Można zestawiać ze sobą obrazy innego/obcego z jakichś dwóch utworów tego samego autora, z utworów dwóch albo kilku autorów bądź z dzieł z różnych epok.

Odnośnie natomiast do badań, jak je określono, zaprojektowanych z rozmachem, a w związku z tym pod względem proceduralnym wieloetapowych, należy stwierdzić, że w gruncie rzeczy całkowicie zależą one od inwencji badacza. Z kolei owa inwencja zależna jest od osadzenia danego naukowca w literaturze przedmiotu, a więc od jego orientacji w imagologii, w tym, co w obrębie tej nauki aktualnie się dzieje, w panujących obecnie na jej polu trendach. Ponadto ma na nią wpływ jego osadzenie w literaturze innych nauk, niekoniecznie humanistycznych. Często bowiem owe odważnie zakreślone rozważania imagologiczne mają charakter interdyscyplinarny. Dziś przede wszystkim badania pomyślane odważnie interesują imagologów, badania zaś wymienione powyżej interesują ich jedynie jako ogniwo pośrednie, tzn. o tyle, o ile prowadzą do badań tego właśnie rodzaju. Gdyby przeto szukać pomysłu na atrakcyjną dla współczesnego odbiorcy refleksję imagologiczną, wiadomo stąd, w jakim kierunku należałoby zmierzać.

Pora teraz na osiem przykładów badań imagologicznych zakrojonych z rozmachem, przy czym ta ośmioelementowa lista oczywiście nie jest zamknięta. Wszystkie te przykłady zostały zaczerpnięte z wielokroć już cytowanego w niniejszym tekście artykułu Joepa Leerssena Imagologia. O zastosowaniu etniczności do nadawania światu sensu. W pracy tej bowiem, choć nie jest to artykuł pomyślany stricte metodologicznie, Leerssen, omawiając dwudziesto- i dwudziestopierwszowieczne dzieje imagologii, wspomina rozmaite analizy, jakie podejmowali kolejni badacze, zwięźle charakteryzując je od strony metodologicznej. Zapoznając się z Leerssenowskimi charakterystykami poszczególnych analiz, można sobie uzmysłowić, jak wiele możliwości stoi otworem przed imagologiem, oraz można szukać inspiracji dla własnych zainteresowań. 
Możliwość pierwsza: Jedna z podstawowych tez przyjmowanych przez imagologów głosi, że aby objąć czy ustrukturyzować świat, w którym przyszło ludziom żyć, co więcej i co chyba też ważniejsze, aby światu temu nadać sens, posługują się oni przede wszystkim pojęciami „charakterów narodowych i temperamentów etnicznych"33. Rzecz jasna, pojęcia te nie są neutralne, gdyż znajdują w nich swój wyraz uprzedzenia i stereotypowe myślenie o ludziach innej narodowości czy grupy etnicznej, ale to oddzielne zagadnienie, które tu się pomija. Jak więc następuje ogarnięcie rzeczywistości i przydanie jej sensu przy wykorzystaniu wspomnianych pojęć? Leerssen stwierdza, że poprzez przyporządkowanie „ludzkiego zachowania do określonego zestawu cech" etnicznych lub narodowych ${ }^{34}$. Jeśli zatem badacz zajmuje się owymi zestawami cech etnicznych lub narodowych, może rekonstruować albo całościowe spojrzenie na świat, albo sens świata, w którym one funkcjonują. Implikują one bowiem spojrzenie na świat i jego sens.

Możliwość druga: Punkt wyjścia stanowi tu zmiana rozumienia autoobrazu, którą zarejestrowali imagolodzy, przyglądając się prowadzonym przez siebie badaniom. Interesującą dla niniejszych rozważań obserwację Leerssen wyraził w następującym zdaniu: „Podczas gdy niegdyś autoobraz uchodził za domyślny punkt wyjścia dla etnocentryzmu, z którego autorzy rozpoczynają opisywanie swojego Fremderfahrung («doświadczenia inności»), obecnie postrzega się go jako złożony konstrukt, wynikający z ciągłej relacji ze zmieniającymi się obrazami inności" ${ }^{35}$. W obrębie analiz imagologicznych można się więc zająć owym autoobrazem jako skomplikowanym produktem tego, co zachodzi pomiędzy nim samym a permanentnie przekształcającymi się związanymi z nim heteroobrazami. Można by np. przyjrzeć się czy to na konkretnym przykładzie, czy w ogólności mechanizmowi, który sprawia, że zmiana w którymś z pozostających z nim w związku heteroobrazów powoduje zmianę w autoobrazie.

Możliwość trzecia: Imagolog może włączyć się w nurt badań nad nacjonalizmem. A to dlatego, że - zdaniem badaczy - nacjonalizm daje się całkiem dobrze zdefiniować za pomocą jednego z zasadniczych pojęć imagologii, mianowicie jako polityczną instrumentalizację autoobrazu ${ }^{36}$. W konsekwencji jest możliwe uważne przyjrzenie się procesowi, w ramach którego dochodzi do owego politycznego zinstrumentalizowania autoobrazu.

Możliwość czwarta: Imagolog może dołączyć do grona zajmujących się studiami nad pamięcią. Wszak w obrębie tych studiów eksploruje się wszelkie nieformalne, nieakademickie, kulturowe - w szerokim sensie tego słowa - sposoby ujmowania swojej przeszłości, przeżytych traum i swoich tradycji przez dane społeczeństwo lub daną wspólnotę w ramach konstruowania swojej tożsamości ${ }^{37}$. Można

33 J. Leerssen, Imagologia ..., art. cyt., s. 10.

34 J. Leerssen, Imagologia ..., art. cyt., s. 10.

35 J. Leerssen, Imagologia ..., art. cyt., s. 19.

36 J. Leerssen, Imagologia ..., art. cyt., s. 20.

37 J. Leerssen, Imagologia ..., art. cyt., s. 20. 
się spodziewać, że imagolodzy mogliby wnieść do dziedziny studiów nad pamięcią ciekawe spostrzeżenia, ponieważ autoobraz, którym się m.in. zajmują, nie jest, jak twierdzą, niczym innym jak tylko kodem tożsamości danego społeczeństwa lub danej wspólnoty.

Możliwość piąta: Otóż etnotypy ze swej natury, jako zjawiska literackie, są dosadne. Można się więc z nimi spotkać najczęściej w gatunkach popularnych, masowych ${ }^{38}$. Za takie gatunki uznaje się przykładowo komedie romantyczne, romanse melodramatyczne i thrillery szpiegowskie. Jednak etnotypy występują także w utworach ambitniejszych, na dalszym planie, jako że postacie drugoplanowe autorzy tego rodzaju dzieł zazwyczaj pozwalają sobie ująć szkicowo i powierzchownie w przeciwieństwie do głównych bohaterów swoich utworów ${ }^{39}$. Przy czym, jak pisze Leerssen, „W «najpoważniejszej» literaturze etnotypy stosuje się przewrotnie, jako część bardziej problematycznego lub złożonego profilu psychologicznego lub ironiczną grę pomiędzy tym, jak ludzie wzajemnie się postrzegają, czego oczekuje od nich świat, jakie jest ich nastawienie do tych oczekiwań i jakie nieporozumienia lub autosugestie z nich wynikają (jak w powieściach E.M. Fostera lub Tomasza Manna). W innym miejscu nazwałem ten styl «ironicznym» i prześledziłem jego różne zastosowania" ${ }^{40}$. Oczywiście Leerssen podaje przykłady takiego ironicznego posłużenia się etnotypem w literaturze, a właściwie to w kulturze. Skoro zatem tak się sprawy mają, to za cel dociekań imagologicznych można by przyjąć odtworzenie roli, jaką etnotyp odgrywa w danym wielowymiarowym profilu psychologicznym. Leerssen konstatuje: „Krytyczna analiza przewrotnego, ironicznego zastosowania etnotypu pozostaje szczególnym wyzwaniem dla analitycznej zdolności imagologa" ${ }^{\text {"1 }}$.

Możliwość szósta: Ironiczne wykorzystanie etnotypów pokazuje, że działają one „raczej na drugim planie niż w formie bezpośrednich tez”42. Owe drugoplanowe etnotypy Hercules Millas określił mianem metaobrazów, twierdząc, że nie są one ,ani autoobrazami, ani heteroobrazami, ale projekcją czegoś pomiędzy nimi”³3. W jaki sposób owe metaobrazy funkcjonują, wyjaśnia krótko Leerssen: „Metaobrazy istnieją wyłącznie poprzez sugerowanie Innym sposobu, w jaki, naszym zdaniem, Oni patrzą na Nas. Co interesujące, ten antagonizm zwykle krystalizuje się na meta-poziomie sugestii. Nieżyczliwość intensyfikuje nie sposób, w jaki My postrzegamy Innych, to, jak My widzimy siebie samych, lub to, w jaki sposób Inni widzą siebie samych albo jak oni widzą nas. Antagonizm pojawia się, kiedy My wyobrażamy sobie, jak Inny myśli o Nas, i kiedy Inni spekulują na temat tego, co My myślimy o Nich”44. Z jednej strony dla zilustrowania, z drugiej zaś dla lepszego objaśnienia

${ }^{38}$ J. Leerssen, Imagologia ..., art. cyt., s. 20.

39 J. Leerssen, Imagologia ..., art. cyt., s. 20.

40 J. Leerssen, Imagologia ..., art. cyt., s. 20.

${ }^{41}$ J. Leerssen, Imagologia ..., art. cyt., s. 21.

42 J. Leerssen, Imagologia ..., art. cyt., s. 21.

${ }_{43}$ J. Leerssen, Imagologia ..., art. cyt., s. 21.

44 J. Leerssen, Imagologia ..., art. cyt., s. 21. 
swoim czytelnikom tego mechanizmu Leerssen omawia zwięźle, jak przebiega on w sytuacji konfliktu: „W czasach konfliktu takie imputacje charakteryzuje niepokojący brak dobrej woli: wierzymy w to, że Inni są winni nieżyczliwości, że nie działają racjonalnie, że żywią głęboką niechęć, i nie zdajemy sobie sprawy, że to My sami uskuteczniamy taką nieżyczliwość i niechęć poprzez przypisywanie jej Innym. Podejrzewamy Innych o bycie podejrzliwymi, nie uświadamiając sobie, że czyniąc to, sami stajemy się podejrzliwi" ${ }^{45}$. W ramach rozważań imagologicznych można by przeto podjąć zagadnienie metaobrazów i ich wpływu na intensywność trwającego między ludźmi antagonizmu, czy to w trakcie konfliktu, czy to w sytuacji bezkonfliktowej. W ten sposób można by dołączyć do grona tych badaczy, którzy zajmują się zarządzaniem konfliktami, proponując im ciekawą, nieznaną im perspektywę oglądu rozpatrywanych przez nich problemów ${ }^{46}$.

Możliwość siódma: Znów trzeba zacząć od tezy, tym razem kognitywno-psychologicznej, która otwiera przed imagologami podwoje nowych rewirów badawczych. W tekście Leerssena, który jest tu bazowy, na temat odnośnej tezy można przeczytać: „Kognitywno-psychologiczny model «ram» i «czynników spustowych» zasadniczo pogłębił naszą wiedzę o etnotypizowaniu i stereotypizowaniu. W dużym uogólnieniu i drastycznym uproszczeniu sprowadza się on do tezy, że w naszym mentalnym instrumentarium posiadamy zestaw «ram» - schematów wiarogodnych połączeń pomiędzy zdarzeniami, a także to, co, naszym zdaniem, stanowi ich ukryty wzorzec. «Ramy» te aktywizowane są przez bieżące bodźce, czyli «czynniki spustowe»; te z kolei powstają ze zdarzeń i doświadczeń w realnym świecie albo z procesów kulturowych w (!) następujących po zwrotach i przełomach narracyjnych" ${ }^{47}$. W konsekwencji zaakceptowania tej tezy imagolodzy przyjęli następną, głoszącą, że etnotypy są właśnie takimi ramami, które okalają zetknięcia się ludzi z rzeczywistością. Leerssen objaśnia rzecz nieco bliżej, zwracając uwagę na dwie kwestie. Najpierw powiada, że etnotypy stanowią fenomen problematyczny z uwagi na swój status ontologiczny, który można określić jako stan połowicznego rozpadu. Leerssen pisze: „Stereotypy i etnotypy są częścią zwykle uśpionego, a nawet ukrytego wachlarza możliwych stanowisk mentalnych. Uśpienie zawsze stanowi domyślny stan etnotypów i uprzedzeń: są w naszych umysłach, nawet jeśli nie jesteśmy ich świadomi”"48. W związku z tym Leerssen zauważa również: „możemy posiadać wiele różnych etnotypów, które nie muszą popadać w konflikty wynikające z ich wzajemnej sprzeczności - każda [bowiem] aktywna rama spycha inne potencjalne ramy do stanu uśpienia"49. I Leerssen podaje tu przykład: kiedy ogląda się komedię z Louisem de Funèsem, to rama-etnotyp energicznego i impulsywnego Francuza zablokuje alternatywę, mianowicie ramę-etnotyp Francuza zdystansowanego, kartezjańsko

\footnotetext{
45 J. Leerssen, Imagologia ..., art. cyt., s. 21.

46 J. Leerssen, Imagologia ..., art. cyt., s. 21.

47 J. Leerssen, Imagologia ..., art. cyt., s. 22.

48 J. Leerssen, Imagologia ..., art. cyt., s. 22.

49 J. Leerssen, Imagologia ..., art. cyt., s. 22.
} 
formalistycznego ${ }^{50}$. Jeśli zatem rozważa się tu rozmaite opcje prowadzenia badań natury imagologicznej, to można wskazać i tę: penetrowanie rzeczywistości etnotypu-ramy, jego-jej funkcjonowania.

I możliwość ósma: Otóż przedmiotem swojego zainteresowania można uczynić zagadnienie relacji, dokładniej: relacji współzależności, wzajemnego wpływu na siebie poszczególnych ram. Okazuje się bowiem, że „etniczność nigdy nie funkcjonuje w izolacji, samodzielnie. Osoba albo postać z nadaną etnicznością zawsze posiada więcej cech niż tylko etniczność" ${ }^{51}$. Zignorowanie tego faktu może bardzo zniekształcić prowadzone badania, albowiem „kiedy tożsamość etniczna staje się cechą esencjalną, a nie przypadkowym atrybutem, każdy czyn ukaże się na tle tego etnicznego pochodzenia, a jednostka będzie zawsze postrzegana jako reprezentant/ reprezentantka jego/jej narodu. Imagolodzy powinni mieć się na baczności" ${ }^{52}$. Etnotypy nie funkcjonują wszak w izolacji, lecz ,działają zawsze w połączeniu z innymi ramami, w szczególności z płcią, wiekiem i klasą"53. Dlatego „postaci literackie zawsze powstają na skrzyżowaniu etnotypu, płci i socjotypu. Imagolodzy mogą wyróżniać pierwszy z tych elementów, ale powinni pamiętać, że rama etniczności nie jest absolutna i nigdy nie funkcjonuje w izolacji” ${ }^{54}$.

\section{Na co imagolog winien uważać?}

Zaprezentowawszy etapy metody imagologii, przechodzi się teraz do wybranych aspektów badań imagologicznych w celu wskazania, na co powinien uważać badacz decydujący się na podjęcie tego typu pracy. Przedstawiany materiał zamyka się tu $\mathrm{w}$ trzech punktach. Punkt pierwszy ma charakter autorski, natomiast w punktach drugim i trzecim przytaczane są uwagi sporządzone przez Joepa Leerssena w artykule Imagologia. O zastosowaniu etniczności do nadawania światu sensu, będącym rodzajem krytycznego retrospektywnego oglądu badań imagologicznych ostatniego stulecia.

Rzecz pierwsza: Zajęcie się obrazem innego/obcego w jakimś tekście w każdym przypadku jest tożsame z podaniem jakiejś interpretacji tego tekstu. Najczęściej jest to interpretacja częściowa, tzn. nie sięgająca rdzenia, istoty owego tekstu i nie wyłuszczająca jego głównej myśli, zasadniczego przesłania, chyba że dotyczy tekstu o problemie etnicznym lub narodowościowym. By kwestię nieco poszerzyć, można dodać, że uprawianie imagologii jest możliwe tylko wtedy, kiedy do zbioru teorii literatury ${ }^{55}$ włączy się teorię literatury imagologiczną. Wyróżnik tej teorii stanowiłoby założenie, że dzieła literackie to tworzywo, w którym

50 J. Leerssen, Imagologia ..., art. cyt., s. 22.

51 J. Leerssen, Imagologia ..., art. cyt., s. 24.

52 J. Leerssen, Imagologia ..., art. cyt., s. 23.

53 J. Leerssen, Imagologia ..., art. cyt., s. 24.

54 J. Leerssen, Imagologia ..., art. cyt., s. 24.

55 Na temat teorii literatury: zob. np. A. Burzyńska, M.P. Markowski, Teorie literatury XX wieku. Podręcznik, Kraków 2007. 
obecny jest pierwiastek imagologiczny. To ważne, by imagolodzy byli świadomi, że podejmowane przez nich badanie niekoniecznie odkrywa sedno tekstu, który analizują. O tym bowiem łatwo mogą zapomnieć. Zresztą niebezpieczeństwo tego zapomnienia czyha na badacza w wypadku każdego innego naukowego postępowania literaturoznawczego.

Rzecz druga: Kwestia tekstu. Jakie teksty wybierać jako podstawę dociekań imagologicznych? Imagolodzy na podstawie swojego doświadczenia odpowiadają: „Zgodnie ze wskazaniem cech moralnych, etnotypy są najwyrazistsze w melodramatycznych, czarno-białych opisach, w których pozytywne lub negatywne cechy piętrzą się w przesadzie, by stworzyć silnie kontrastujące wzorce «dobrych» i «złych» lub aktanty takie jak Bohater, Łajdak, Ofiara albo Przyjaciel. Etnotypy znajdujemy więc najczęściej w gatunkach takich jak komedia sentymentalna i powieść popularna lub powieść dziecięca (w szczególności w okresie 1700-1950). Bardziej skomplikowane postaci w poważnych narracjach zwykle mają sprzeczne albo zniuansowane profile moralne z, w szczególności od końca XIX wieku, silną tendencją do ironicznego, niejednoznacznego usposobienia albo niejasnej motywacji do działania. Jednak nawet $w$ takich narracjach postaci drugoplanowe zwykle zakreślone są mniej detalicznie, bardziej szkicowo, w większej zależności od etnotypów" ${ }^{\prime 5}$. Trudno orzec o tej uwadze, że nie jest relewantna. Podkreśla przecież potrzebę dobrania tekstu odpowiedniego do profilu badań. W przeciwnym bowiem razie całe przedsięwzięcie badawcze już u swego zarania może zostać skazane jeśli nie na porażkę, to przynajmniej na jakieś poważne niedostatki.

Odnośnie do tekstu imagolodzy zwracają jeszcze uwagę na dwie sprawy. Po pierwsze, że uprzywilejowany gatunek literacki stanowią w ich oczach opowiadania, zarówno fikcyjne, jak i niefikcyjne. A to dlatego, że w opowiadaniach zasadniczo przedstawia się motywację bohaterów do działań określonego rodzaju, która - jak już wspomniano - interesuje imagologów. W niej to bowiem szukają oni elementu narodowego jako czynnika wyjaśniającego ${ }^{57}$. Po drugie, jakakolwiek analiza tekstu musi być jednocześnie - zdaniem imagologów - trójaspektowa czy trójwymiarowa. Leerssen mówi o analizie tekstowej, intertekstowej oraz kontekstowej. Pierwsza ma się w jego opinii „składać z faktycznego studium samego tekstu, by ukazać, jak funkcjonuje w nim etnotyp [...], czy jest pierwszoplanowy, do jakiego stopnia kontrastuje $\mathrm{z}$ innymi typami narodowymi, z założonym autoobrazem lub projektowaną publicznością, czy jego obecność w tekście jest podkreślona, neutralizowana, ironizowana, czy pozostawiona bez ingerencji autora i ogólnej fokalizacji oraz toku tekstu. Jeśli dany bohater w tekście zostaje określony jako narodowość X, jaką różnicę sprawiłoby, gdyby narodowość danego bohatera była Y lub Z, tj. jaką rolę wła-

\footnotetext{
56 J. Leerssen, Imagologia ..., art. cyt., s. 16.

57 J. Leerssen, Imagologia ..., art. cyt., s. 14.
} 
ściwie gra tu narodowość?" 58 . Z kolei celem analizy intertekstowej jest, jak ujmuje to Leerssen, „prześledzenie papierowego szlaku tekstualnej obecności danego miejsca wspólnego" 59 , czyli w tym przypadku określonej charakterystyki etnicznej. Okazuje się bowiem, że ,profil charakterologiczny danego etnotypu jest końcowym efektem długiej akumulacji pojedynczych instancji tekstowych, a ta akumulacja z kolei stanowi tło, na którym odbija się indywidualny przypadek. W istocie każdy przykład danego etnotypu odnosi się nie tyle do rzeczywistości empirycznej, ale do ustalonych miejsc wspólnych, a zadaniem imagologa jest wyrwanie tych miejsc wspólnych ze stanu uśpionych, ukrytych znaczeń «rzeczy, które ktoś kiedyś usłyszał, nie pamiętając dokładnie, gdzie i kiedy»" ${ }^{\prime 60}$. Wreszcie zadaniem, jakie podejmuje się w ramach analizy kontekstowej, jest prześledzenie wszelkich warunków, w których urzeczywistnia się dany etnotyp, tj. warunków historycznych, politycznych i społecznych ${ }^{61}$, ponieważ zapoznanie się z nimi pozwala dany etnotyp zrozumieć. Trzeba przyjrzeć się konkretnemu etnotypowi w szerokiej perspektywie. Leerssen zauważa: „Powinniśmy wiedzieć, że w historii literatury dla rozumienia tekstu liczy się nie tylko moment jego publikacji”' ${ }^{\prime 2}$. Drugim ważnym elementem pozwalającym rozumieć tekst jest jego recepcja. Leerssen stawia to zagadnienie, wspominając o antysemityzmie Szekspirowskiego Kupca weneckiego: „Czy możemy wystawiać sztukę z wyrazistymi elementami antysemickimi po Auschwitz? Jeśli nie, czy to oznacza, że musimy retrospektywnie wykluczyć Szekspira za antysemityzm, który doprowadził do ludobójstwa 350 lat po powstaniu jego sztuki? Jeśli tak, czy jako publiczność musimy udawać, że jesteśmy jak Szekspir, nietknięci przez Auschwitz?"63.

W końcu rzecz trzecia, najobszerniejsza. Otóż przedstawia się niżej pięć spraw, z którymi naukowiec musi być zaznajomiony, jeżeli zależy mu na poprawnym przeprowadzeniu imagologicznej procedury badawczej.

Po pierwsze, etnotypy, a więc rzeczywistość, którą zajmuje się imagolog, to konstrukty, których podstawową cechą jest zmienność: „Etnotypy są niewątpliwie bytami historycznymi, chociaż pretendują do miana dysponentów niezmiennej prawdy" ${ }^{\circ 4}$. Imagolodzy mówią negatywnie w tym kontekście o antyesencjalizmie. Każdy etnotyp przekształca się na przestrzeni lat i wieków. Przekształcenia te dokonują się zazwyczaj „nagle, po osiągnięciu punktu krytycznego, w którym utrzymujący się przez długi czas etnotyp nagle ustępuje jego przeciwieństwu (albo zostaje przez nie wyparty)" ${ }^{65}$. W konsekwencji istotne jest, aby imagolodzy starali się uchwycić owe transformacje i umieścić je w określonym czasie. Aby usiłowali wskazać, w którym

58 J. Leerssen, Imagologia ..., art. cyt., s. 18.

59 J. Leerssen, Imagologia ..., art. cyt., s. 16.

60 J. Leerssen, Imagologia ..., art. cyt., s. 17.

${ }^{61}$ J. Leerssen, Imagologia ..., art. cyt., s. 17.

62 J. Leerssen, Imagologia ..., art. cyt., s. 17.

63 J. Leerssen, Imagologia ..., art. cyt., s. 17.

${ }^{64}$ J. Leerssen, Imagologia ..., art. cyt., s. 15.

65 J. Leerssen, Imagologia ..., art. cyt., s. 15. 
momencie nastąpiły punkt krytyczny i wskutek tego przeobrażanie się jednego etnotypu w drugi.

Po drugie, poszczególne etnotypy przeciwstawiają się sobie nawzajem. Leerssen pisze: „Etnotypy są albo eksplicytnie, albo implicytnie kontrastywne. Odwołują się do opozycji pomiędzy Swoim a Obcym (autoobraz vs. heteroobrazy, etnocentryzm vs. egzotyzm lub ksenofobia) i/lub budują dany typ narodowy w opozycji do rzekomego planu różnic od innych typów narodowych" ${ }^{\prime 6}$. W związku z tym, że taka jest natura etnotypów, istnieją dyskursywno-retoryczne rezerwuary „etnotypizujących stwierdzeń na temat danego narodu" ${ }^{\prime \prime}$. Każdy z owych rezerwuarów - nazywa się je imagenami - ,jest zbiorem wielowarstwowych, historycznych nagromadzeń wyraziście sprzecznych elementów: obrazów i przeciwobrazów”68. Leerssen wyjaśnia: „Wewnętrzne sprzeczności w ramach danego imagenu sprawiają, że etnotyp jest niefalsyfikowalny: każdy przykład zaprzeczający twierdzeniu zgodnemu z etnotypem będzie potwierdzał inny dostępny wariant w ramach tego imagenu. Sprzeczności wewnątrz imagenu często będą ulegać racjonalizacji poprzez przypisywanie tych opozycji samemu narodowi jako typowo dwubiegunowemu «narodowi sprzeczności»" ${ }^{99}$.

Po trzecie, imagolog zajmuje się etnotypem dlatego, że interesuje go wyjaśnienie postępowania, a etnotyp właśnie takiego wyjaśnienia mu dostarcza. Leerssen powiada: „Typ narodowy ma dostarczać logicznego związku pomiędzy bohaterami historii a wydarzeniami w historii" ${ }^{70}$. Wynika to $\mathrm{z}$ faktu, że ludzie Zachodu są dziedzicami narracyjnej schedy Arystotelesa, którą ten zawarł w swojej Poetyce. Konwencja zachodniej narracji post-Arystotelesowskiej stara się oddać zachowanie postaci, jej wybory i działania jako umotywowane, tj. logicznie uzasadnione i spójne w odniesieniu do typu osoby, jaką jest określony bohater. W kontekście etnotypów umotywowanie to często wiąże się z narodowością jako czynnikiem wyjaśniającym charakterystyczne wybory/decyzje i działania danego bohatera - nawet te wyraźnie niekonsekwentne ${ }^{71}$. Ujmując kwestię negatywnie: „Opisy określonego narodu, które w żaden sposób nie wyjaśniają narodowych cech za pomocą domniemanego ukrytego typu narodowego, nie są etnotypami i pozostają poza kręgiem zainteresowań badań imagologicznych"72.

Po czwarte, prowadząc badania imagologiczne, trzeba zachować czujność, by nie pomylić etnotypu z typem ponadnarodowym. Łatwo o taką pomyłkę. Nierzadko bowiem zdarza się, że etnotyp, stanowiąc odpowiedź na potrzebę rozróżnienia narodowościowego, opiera się ukrytych wzorach temperamentów, które nie są sprzę-

66 J. Leerssen, Imagologia ..., art. cyt., s. 13.

${ }^{67}$ J. Leerssen, Imagologia ..., art. cyt., s. 15.

68 J. Leerssen, Imagologia ..., art. cyt., s. 15; por. S. Scherer, Imagination, Imaginary, w: Imagology..., dz. cyt., s. 345-347.

69 J. Leerssen, Imagologia ..., art. cyt., s. 15.

70 J. Leerssen, Imagologia ..., art. cyt., s. 14.

71 J. Leerssen, Imagologia ..., art. cyt., s. 14.

72 J. Leerssen, Imagologia ..., art. cyt., s. 14. 
gnięte z narodowością. Tymczasem owe ponadnarodowe wzory temperamentów wykorzystuje się w innych celach, np. dla „ukazania różnic pomiędzy makroregionami $[\ldots]$ albo regionami wewnątrz kraju" "73. Jako przykłady opozycji temperamentów nienarodowych można wskazać „opozycję temperamentów pomiędzy chłodną, zdystansowaną, umoralnioną Północą i gorącym, sangwinicznie emocjonalnym Południem; pomiędzy dynamicznym centrum a statycznymi albo zacofanymi peryferiami”74. I Leerssen kontynuuje: „Wschodnie obszary często łączy się z reżimami despotycznymi, zachodnie - z wartościami demokratycznymi; ponadto standardowe opozycje w typach narodowych przywoływane są często w rywalizacji pomiędzy narodami bazującymi na honorze a narodami opartymi na statusie oraz obowiązku i umowie" ${ }^{\prime 7}$. Warto zaznaczyć, że to, jak wymienione czy im podobne wzorce temperamentów zostaną wpisane w etnotypy, jest rzeczą zmienną. Leerssen stwierdza: „Każdy naród może [...] zostać skonfigurowany w taki sposób, by podzielał wartości północne lub południowe, centralne lub peryferyjne, silne lub słabe, arystokratyczne lub burżuazyjne" 76 .

Po piąte wreszcie, etnotypy splatają się z waloryzacją albo pozytywną, albo negatywną, zależnie od obecnych sympatii. Leerssen wyjaśnia, jak do takiej waloryzacji dochodzi: „Może się to odbywać na dwa sposoby: albo dany etnotyp zostaje zastąpiony przez alternatywny, odwrotnie waloryzowany przeciwobraz («Irlandczycy nie są brutalnymi, nieoświeconymi terrorystami, ale wrażliwymi marzycielami nie z tego świata»), albo samemu etnotypowi przypisana zostaje inna waloryzacja («Irlandczycy, wrażliwi marzyciele nie z tego świata, są irytująco nieprzystosowani do życia praktycznego»)" "77. Najczęstszym sposobem waloryzacji jest atrybucja moralna. Dowartościowuje się bohatera, gdy przypisuje się mu następujące cechy: „posiadanie harmonijnego życia rodzinnego (co objawia się w szczęściu małżeńskim oraz w pełnej miłości relacji pomiędzy rodzicem a dziećmi), gościnność, uczciwość, etyka w pracy i wierność danemu słowu. Przeciwne cechy odpowiednio umieszczą bohatera w negatywnym świetle"78. Ciekawą własnością jest pobożność. $Z$ jednej strony może bowiem być wartością pozytywną, lecz z drugiej może też być wartością negatywną, jeśli nadaje się jej postać „przesądności, bigoterii i fanatyzmu"79. Waloryzacja może oczywiście ulegać zmianom. Leerssen podaje taki przykład rzeczonej zmiany: „W relacjach międzynarodowych w okresach stabilności występuje zwykle tendencja do ukrócenia etnotypizacji na

73 J. Leerssen, Imagologia..., art. cyt., s. 15; por. J. Leerssen, Region, w: Imagology..., dz. cyt., s. 412-415; M. Beller, East/West, w: Imagology..., dz. cyt., s. 315-319; A. Arndt, North/South, w: Imagology..., dz. cyt., s. 387-389.

74 J. Leerssen, Imagologia ..., art. cyt., s. 14.

75 J. Leerssen, Imagologia ..., art. cyt., s. 14.

76 J. Leerssen, Imagologia ..., art. cyt., s. 14-15.

77 J. Leerssen, Imagologia ..., art. cyt., s. 15.

78 J. Leerssen, Imagologia ..., art. cyt., s. 15.

79 J. Leerssen, Imagologia ..., art. cyt., s. 15. 
rzecz trendu zmierzającego w stronę typowej neutralności i normalności («Ten naród jest taki jak my / taki jak każdy inny»), momenty napięcia wzmacniają etnotypizację ( «Anglicy/Francuzi/Węgrzy stawiają czoła kryzysowi z charakterystycznym XYZ ...»)" ${ }^{\prime 80}$.

\section{Podsumowanie}

W ramach podsumowania przeprowadzonego wywodu można wyrazić nadzieję, że zastosowanie zaprezentowanej $\mathrm{w}$ nim procedury naukowej $\mathrm{w}$ analizie dzieł literackich doprowadzi do wielu nowatorskich, ciekawych wniosków. Wnioski te przede wszystkim odkryją - na tyle, trzeba zastrzec, na ile literatura stanowi zwierciadło świata - jak ludzie jako należący do różnych grup, wspólnot etnicznych i narodów widzą siebie nawzajem; wnioski te uświadomią różne procesy zachodzące w ramach rzeczywistości wzajemnego postrzegania się, odsłonią rozmaite mechanizmy, które rządzą odnośną rzeczywistością, do czego nie daje przystępu żadna inna metoda. W konsekwencji niejednego można się będzie z dociekań imagologicznych dowiedzieć o sobie; można będzie zrozumieć, dlaczego ludzie tak, a nie inaczej patrzą na siebie nawzajem. Niewykluczone, że w ten sposób da się wydatnie dopomóc w wyrywaniu się ludzi z rozmaitych ograniczeń, w jakich są uwięzieni, w jakich tkwią w sferze wzajemnych relacji, wzajemnego współżycia. Pozwalają żywić taką wiarę dotąd opublikowane badania imagologiczne.

\section{Bibliografia}

Agamben G., Homo sacer. Suwerenna władza i nagie życie, thum. M. Salwa, Warszawa 2008.

Arndt A., North/South, w: Imagology: The Cultural Construction and Literary Representation of National Characters: A Critical Survey, eds. M. Beller, J. Leerssen, Studia Imagologica 13, Amsterdam-New York 2007, s. 387-389.

Baumann Z., Obcy u naszych drzwi, Warszawa 2019.

Beller M., East/West, w: Imagology: The Cultural Construction and Literary Representation of National Characters: A Critical Survey, eds. M. Beller, J. Leerssen, Studia Imagologica 13, Amsterdam-New York 2007, s. 315-319.

Beller M., Stereotype, w: Imagology: The Cultural Construction and Literary Representation of National Characters: A Critical Survey, eds. M. Beller, J. Leerssen, Studia Imagologica 13, Amsterdam-New York 2007, s. 429-434.

Benedyktowicz Z., Portrety „obcego”. Od stereotypu do symbolu, Kraków 2000.

Bronk A., Metoda naukowa, w: Encyklopedia katolicka, red. Stanisław Wilk i in., t. 12, Lublin 2008, k. 637-644.

Buber M., Ja i Ty. Wybór pism filozoficznych, tłum. J. Doktór, Warszawa 1992.

$\overline{80}$ J. Leerssen, Imagologia ..., art. cyt., s. 15. 
Buchowski M., Zrozumieć Innego. Antropologia racjonalności, Kraków 2004.

Burzyńska A., Markowski M.P., Teorie literatury XX wieku. Podręcznik, Kraków 2007.

Corbey R., Anthropology, w: Imagology: The Cultural Construction and Literary Representation of National Characters: A Critical Survey, eds. M. Beller, J. Leerssen, Studia Imagologica 13, Amsterdam-New York 2007, s. 263-266.

Dyserinck H., Komparatistik: Eine Einführung, Bonn 1997.

Dyserinck H., Von Ethnopsychologie zu Ethnoimagologie: Über Entwicklung und mögliche Endbestimmung eines Schwerpunkts des ehemaligen Aachener Komparatistikprograms, „Neohelicon” 29 (2002), Nr. 1, s. 57-74.

Gruchlik H., Inność a obcość w kontekście filozoficznym, „Anthropos?” (2007), nr 8-9, anthropos.us.edu.pl/anthropos5/texty/gruchlik.htm [dostęp: 15 XII 2020 r.].

Hajduk Z., Ogólna metodologia nauk, Lublin 2012.

Hölter A., Colonialism, w: Imagology: The Cultural Construction and Literary Representation of National Characters: A Critical Survey, eds. M. Beller, J. Leerssen, Studia Imagologica 13, Amsterdam-New York 2007, s. 304-306.

Kapuściński R., Ten Inny, Kraków 2020.

Kotarbiński T., O pojęciu metody, Warszawa 1957.

Leerssen J., Identity/Alterity/Hybridity, w: Imagology: The Cultural Construction and Literary Representation of National Characters: A Critical Survey, eds. M. Beller, J. Leerssen, Studia Imagologica 13, Amsterdam-New York 2007, s. 335-342.

Leerssen J., Image, w: Imagology: The Cultural Construction and Literary Representation of National Characters: A Critical Survey, eds. M. Beller, J. Leerssen, Studia Imagologica 13, Amsterdam-New York 2007, s. 342-344.

Leerssen J., Imagologia. O zastosowaniu etniczności do nadawania światu sensu, tłum. E. Kledzik, „Porównania” 21 (2017), nr 2, s. 9-30.

Leerssen J., Imagology: History and Method, w: Imagology: The Cultural Construction and Literary Representation of National Characters: A Critical Survey, eds. M. Beller, J. Leerssen, Studia Imagologica 13, Amsterdam-New York 2007, s. $17-32$.

Leerssen J., Nation, Ethnie, People, w: Imagology: The Cultural Construction and Literary Representation of National Characters: A Critical Survey, eds. M. Beller, J. Leerssen, Studia Imagologica 13, Amsterdam-New York 2007, s. 377-381.

Leerssen J., Region, w: Imagology: The Cultural Construction and Literary Representation of National Characters: A Critical Survey, eds. M. Beller, J. Leerssen, Studia Imagologica 13, Amsterdam-New York 2007, s. 412-415.

Leerssen J., The Poetics and Anthropology of National Character (1500-2000), w: Imagology: The Cultural Construction and Literary Representation of National Characters: A Critical Survey, eds. M. Beller, J. Leerssen, Studia Imagologica 13, Amsterdam-New York 2007, s. 63-75. 
Lévinas E., Całość i nieskończoność. Esej o zewnętrzności, thum. M. Kowalska, Warszawa 2002.

Millas H., The Imagined „Other” as National Identity: Greeks and Turks, Ankara 2005.

Mitchelli T., What Is an Image?, w: Imagology: Images, Text, Ideology, ed. by T. Mitchelli, Chicago 1986, s. 7-46.

Nippel W., Ethnic Images in Classical Antiquity, w: Imagology: The Cultural Construction and Literary Representation of National Characters: A Critical Survey, eds. M. Beller, J. Leerssen, Studia Imagologica 13, Amsterdam-New York 2007, s. 31-44.

Obcy/Inny - propozycje aplikacji pojęciowych, red. M. Karwatowska i in., Lublin 2018.

Pageaux D.H., De l'image à l'imaginaire, „Colloquium Helveticum” (1988), nr 7, s. 9-16.

Przyklenk J., Od identyczności do różnicy-uwagi o pojęciu tożsamości w najnowszej historii polszczyzny, w: Naukovi zapiski nacionalnogo universitetu „Ostroz'ka akademia”, Kulturologia 18, Ostrog 2017, s. 61-70.

Riesz J., Postcolonialism, w: Imagology: The Cultural Construction and Literary Representation of National Characters: A Critical Survey, eds. M. Beller, J. Leerssen, Studia Imagologica 13, Amsterdam-New York 2007, s. 400-403.

Rigney A., Discourse, w: Imagology: The Cultural Construction and Literary Representation of National Characters: A Critical Survey, eds. M. Beller, J. Leerssen, Studia Imagologica 13, Amsterdam-New York 2007, s. 313-315.

Rigney A., Representation, w: Imagology: The Cultural Construction and Literary Representation of National Characters: A Critical Survey, eds. M. Beller, J. Leerssen, Studia Imagologica 13, Amsterdam-New York 2007, s. 415-418.

Rigney A., Semiotics, w: Imagology: The Cultural Construction and Literary Representation of National Characters: A Critical Survey, eds. M. Beller, J. Leerssen, Studia Imagologica 13, Amsterdam-New York 2007, s. 421-424.

Scherer S., Imagination, Imaginary, w: Imagology: The Cultural Construction and Literary Representation of National Characters: A Critical Survey, eds. M. Beller, J. Leerssen, Studia Imagologica 13, Amsterdam-New York 2007, s. 345-347.

Słownik grecko-polski, red. Z. Abramowiczówna, t. 3, Warszawa 1962.

Słownik języka polskiego, red. W. Doroszewski, Warszawa 1958-1969, sjpd.pwn.pl [dostęp: 15 XII 2020 r.].

Stownik łacińsko-polski, red. M. Plezia, t. 3, Warszawa 2007.

Środa M., Obcy, inny, wykluczony, Gdańsk 2020.

Tatarkiewicz W., O pisaniu historii filozofii, w: W. Tatarkiewicz, O filozofii i sztuce, Warszawa 1986, s. 63-86.

Tischner J., Filozofia dramatu, Kraków 2006. 
Tischner J., Inny. Eseje o spotkaniu, Kraków 2017.

Todorov T., Podbój Ameryki. Problem innego, thum. J. Wojcieszak, Warszawa 1996. Waldenfels B., Topografia obcego. Studia z fenomenologii obcego, thum. J. Sidorek, Warszawa 2002.

\section{Streszczenie}

Niniejszy artykuł ma na celu przygotowanie badacza literaturoznawcy do prowadzenia dociekań imagologicznych. Tekst ma więc z jednej strony charakter wprowadzający i instrukcyjny, z drugiej zaś przeglądowy i syntetyczny. Składają się nań cztery części: 1) wyjaśnienie trzech podstawowych pojęć imagologicznych: innego/ obcego, obrazu oraz etnotypu; 2) omówienie sposobu doboru materiału źródłowego do badań imagologicznych; 3) charakterystyka możliwych sposobów opracowania wyselekcjonowanego materiału tekstowego, a zatem możliwych profili badań imagologicznych; 4) prezentacja kilku najważniejszych ustaleń imagologii i wskazanie związanych z nimi momentów analizy imagologicznej, w których badacz winien zachować szczególną ostrożność.

Slowa kluczowe: imagologia, literaturoznawstwo, metodologia, obraz, inny, obcy

\section{On the Method of Imagological Inquiry}

\section{Summary}

The aim of this study is to prepare the literary researcher to conduct imagological research. The text is therefore introductory and instructional on the one hand and reviewing and synthetic on the other. It consists of four parts: (1) an explanation of three basic imagological concepts: other / alien, image, and ethnotype; (2) a discussion of the way in which source material for imagological research is collected; (3) the characteristics of the possible ways of developing the selected text material and therefore possible profiles of imagological research; (4) a presentation of some of the most important findings of imagology and an indication of the related moments of imagological analysis, in which the scholar should exercise particular caution.

Key words: imagology, literary studies, methodology, image, other, alien 